\title{
Learning Model Development of Indonesian Phonology and Psycholinguistics Through Contextual Approach in Surakarta Universities
}

\author{
Tutik Wahyuni \\ Universitas Veteran Bangun Nusantara \\ Sukoharjo, Indonesia \\ tutik21161@gmail.com
}

\begin{abstract}
Indonesian Phonology and Psycholinguistics generally only touch the theories about the sound production that leads to an insufficient process of speech therapy learning. Educators are responsible for providing and developing an accessible, efficient and effective teaching instruments and materials for daily application. This article aims to (1) describe and explain Phonology and Psycholinguistics in the boundary of Indonesian Language and Literature study; (2) describe and explain the teaching models for Phonology and Psycholinguistics based on the student needs analysis; and (3) describe and explain the prototype for Phonology and Psycholinguisticslearning instruments through a Contextual Approach. In particular, it seeks the development of teaching materials for Phonology and Psycholinguistics through a Contextual Approach to accommodate the Indonesian Language and Literature students' learning process in Surakarta universities. It applies the Research and Development (R\&D) method through four procedures, including (1) exploration; (2) design; (3) experiment; and (4) dissemination.
\end{abstract}

Keywords - contextual approach, development, phonology and psycholinguistics.

\section{INTRODUCTION}

This article conveys the urgency of learning instruments in helping students explore Indonesian Phonology and Psycholinguistics.The application of speech therapy through a Contextual Approach may help them deal with this issue. It aims to (1) describe the current Indonesian Phonology and Psycholinguistics learning instruments; (2) developing a prototype for an appropriate Indonesian Phonology and Psycholinguistics learning instruments with a speech therapy sub-subject; (3) use an innovative learning instrument in conveying Phonology and Psycholinguistics as the introductory to Indonesian Syntax.

It develops Indonesian Phonology and Psycholinguistics learning instruments through a Contextual Approach for Surakarta universities. This attempt is established based on the belief that learning process strongly relies on the innovative learning cycles [3] in producing an academic outcome [5].

The application of Contextual Approach for classroom may have several procedures, including (1) set an atmosphere to encourage students in constructing a learning process using their skills and competencies; (2) hold inquiries for all units of activities; (3) encourage students to ask further explanation; (4) initiate a learning community; (5) develop new learning models for particular topics; (6) hold reflection at the end of the session; and (7) hold a valid assessment using various combinations.

Previously, [15], [16], [17], and [18] had studied the learning model development for Indonesian Syntax through a Contextual Approach. Those initial studies have influenced this research in spanning the boundary of Phonology and Psycholinguistics.Its interest mainly falls on the specific topic in engaging both Phonology and Psycholinguistics with a speech therapy material focus as a sub-subject. This idea attempts to generate more attention in developing the detail of instruments.

Another similar study came from [11] who had integrated games for classic music learning model through four stages of implementation, including demonstration, observation, reflection, and discussion. The findings confirm a significant improvement for comprehension of the subject.

\section{MATERIALS AND METHODS}

This study applies Gall, [1] Research and Development (R\&D) method, aiming to produce a new systematical procedure. After the realization of the product, a small-scale experiment will come before the evaluation and improvement for several qualifications.

\section{A. Preliminary Study}

The preliminary study applies a Descriptive Method, aiming to (1) evaluate the recent Indonesian Phonology and Psycholinguistics learning instruments; (2) attach discussion about speech therapy as a new sub-subject in Indonesian Phonology and Psycholinguistics based on a need analysis; and (3) convey speech therapy sub-subject in a small-scale experiment

\section{B. Data Collecting Technique}

This article refers to [9] for the data collecting technique that comprises several procedures, including (1) hold an indepth interview with students and faculties in evaluating the recent Indonesian Phonology and Psycholinguistics learning instruments; (2) distribute questionnaires in exploring the lecture procedures, such as classroom activities, instruments, and material focus.

\section{Data Analysis}

This study uses Mc Donough and Mc Donough's data analysis technique (Cohen, Manion, Morrison, 2007: 10) which falls into (1) analysis; (2) revision for the correlation among sub-subjects and material briefs; and (3) verification 
through a peer-debriefing technique to generate accuracy and credibility

\section{RESULTS AND DISCUSION}

This article proves that current Indonesian Phonology and Psycholinguistic learning instruments lack several important aspects. In regards to improve the quality of those learning instruments, there are pieces of advice based on the need analysis, including (1) implement a new policy in introducing Phonology and Psycholinguistics as essential subjects in lecture; (b) boost lecturers' capability in producing Phonology and Psycholinguistics learning instruments based on the students' need analysis; and (c) apply a Contextual Approach in creating innovative and constructive teaching methods.

The development of Indonesian Phonology and Psycholinguistic learning instrumentsis firstly designed as a prototype. Its uses content validity which depends on the consistency of theresult from time to time(Nursalam, 2002), in addition to a reliability test.

The findings confirm that a Contextual Approach works better than Conventional Approach. It is effective in constructing a learning interaction among students and reducing their spoon-feeding habit. This study is relevant to Chaer (2009) and [12] who came across that a Contextual Approach effectively encourages students in the learning process. This approach emphasizes the students' independence in understanding Phonology and Psycholinguistics through a peer-learning.

Sitepu (2008) conveyed that a shift of paradigm in education will potentially trigger a disposition in the learning process. Therefore, this article recommends an innovative, effective and convenient learning instrument to sustain long-term learning comprehension.

A Contextual Approach has appeared as an innovative learning strategy for Indonesian Syntax. It consists of six elements, including constructivism, inquiry, modeling, community learning, reflection, and authentic assessment. At the first stage, the development uses a prototype of Phonology and Psycholinguistics learning instruments through gradual experiments in Surakarta universities. The small-scale experiment sets in University of Veteran Bangun Nusantara University. It firstly provides an inquiry cycle which comprises of several questions, including (1) what is speech therapy?; (2) how is speech therapy perceived from its smallest units (syllable, word, phrase, clause, and sentence)?; (3) why could the discussion about speech therapy create a concept of study?; and (4) how is the theory of speech therapy implemented?.

\section{CONCLUSION}

This study had garnered a positive response from stakeholders, academic authors, lectures, and students. It concludes that the lecture on Indonesian Phonology and Psycholinguistics through a Contextual Approach is wellreceived and well-disseminated. The attachment of speech therapy as a sub-subject within the boundary of Phonology and Psycholinguistics must refer to the faculties and students' need analysis.

\section{ACKNOWLEDGMENT}

The author would like to thank to the leader of University of Veteran Bangun Nusantara Sukoharjo.

\section{REFERENCES}

[1] Gall, D. Meredith, Joyce P. Gall\& W.R. Borg. Educational Research and Introduction (Seven Edition). New York: Pearson Education, Inc.J. Clerk Maxwell, A Treatise on Electricity and Magnetism, 3rd ed., vol. 2. Oxford: Clarendon, 1892, pp.68-73. 2003.

[2] Johnson, Elaina B. CTL: Contextual Teaching \& Learning. Terj. Ibnu Setiawan. Bandung : Kaifa Learning. 2010.

[3] In'am, A. and Hajar, Siti. "Learning Geometry through Discovery Learning Using a Scientific Approach". International Journal of Instruction. Vol.10 No. 1: 556-66. 2017.

[4] Kirschner, P.A., Sweller, J. \& Clark, R.E. "Why Minimal Guidance During Instruction Does Not Work: An analysis of The Failure of Constructivists, Discovery, Pro-Blebased, Experimental, And InquiryBased Teaching. Educational Psycho-logist, 41, 75-86. 2006.

[5] Lim, D. H., \& Morris, M. L. Learner and Instructional Factors Influencing Learning Outcomes within A Blended Learning Environment. Educational Technology \& Society,12 (4), 282-293. 2009.

[6] Martins, O. O. and Oyebanji, R. K. The Effects Of Inquiry and Lecture Teaching Approaches on The Cognitive Achievement of Integrated Science Students. Journal of Science Teachers' Association of Nigeria. 35 (1\&2) 25-30. 2000.

[7] Rahayu, Sri, I.W. Rasma, G. Artawan. "Penerapan Model Pembelajaran Komtekstual dalam Pembelajaran Menulis Pada Siswa Kelas XII SMKN 1 Denpasar". Jurnal Penelitian Pascasarjana Undikha. Vol. 2: 1--13. 2013.

[8] Richards, Jack C..danRodgers, Theodore S. Approach and Methods in Language Teaching. Cambridge: Cambridge University Press. 2014

[9] Sukmadinata, Nana Syaodih. Metode Penelitian Pendidikan. Bandung: P.T.Remaja Rosdakarya. 2012.

[10] Supriyadi. "Pengembangan Model Pembelajaran Menulis Karya Ilmiah Berpendekatan Konstruktivisme". .LITERA: Jurnal Penelitian, Bahasa, Sastra, dan Pengajarannya. Vol. 14 No. 2: 361-375. 2015.

[11] Sato, Aiko, JonathandeHaan. "Applying an Experiential Learning Model to the Teaching of Gateway Strategy Board Games".International Journal of Instruction, January 2016. Vol.9 No. 1. 2016.

[12] Sidu, La Ode. Sintaksis Bahasa Indonesia. Kendari: Unhalu Press. 2012.

[13] Sugiyono. Metode Penelitian Kuantitatif Kualitatif dan $R \& D$. Bandung: CV Alfabeta. 2012.

[14] Tomlinson, Brian \&Mashuhara, Hitomi. Developing Language Course Materials. Singapore: SEAMEO Regional Language Centre. 2004.

[15] Wahyuni, Tutik, Sarwiji S, St.YSlamet, Andayani. The Implementation of Contextual Approach in Solving Problems Understanding Syntax Sentence Indonesian at Universities in Surakarta, Indonesia. (2015).

[16] Wahyuni, Tutik, Sarwiji S, St.Y Slamet, Andayani. The Content of Indonesian Language Syntactic Learning Instrument Based on The Need Analysis Directed to The Indonesian Language And Literature Education Departement Students Among The Universities in Surakarta Indonesia. Anatolian Journal of Education. Vol.1 No.3. 110. (2017a)

[17] Wahyuni, Tutik, Sarwiji S, St.Y Slamet, Andayani.. Development of Teaching Materials Syntax: Indonesian Sentence Contextual Approach to EducationforIndonesianLanguage and LiteratureStudents in Surakarta Indonesia. ProceedingsCambodia 2017.P 1052. (2017b).

[18] Wahyuni, Tutik, Sarwiji S, St.YSlamet, Andayani. Contextual Approach to The Development of An Indonesian Syntax Texbook in Higher Education in Indonesia. International Journal of Instruction. Vol.11 No 1. 211-226. (2018) 